Media Industries 5.2 (2018)

\title{
Internet-Distributed Television Research: A Provocation
}

\author{
Amanda D. Lotz, Ramon Lobato, and Julian Thomas ${ }^{1}$ \\ UNIVERSITY OF MICHIGAN AND RMIT UNIVERSITY \\ amanda.lotz@qut.edu.au
}

\begin{abstract}
From Netflix and Hulu to iPlayer and iQiyi, the rapid growth of internetdistributed television services worldwide presents both opportunities and challenges for media industry scholars. Which business models are succeeding in different countries, and why? What frameworks help us explain and talk about television amid such a variety of industrial practices? This article provides a critical overview of the emerging research landscape and suggests future lines of inquiry. We offer seven provocations regarding specific issues in internet-distributed television research-theory, comparison, market definition, historiography, regulation, user experience, and industry transformation. ${ }^{2}$
\end{abstract}

Keywords: Internet Television, Internet-Distributed Television, Streaming, Video on Demand, Global Television

The rapid growth of internet-distributed television services worldwide presents an array of research opportunities, challenges, and possibilities of transnational comparison. Recent scholarship has explored this developing terrain and sought to create conceptual frameworks that enable understandings broader than particular cases. ${ }^{3}$ While most of the existing research has been conducted within a national frame, the prospect of a multisited analysis brings new and interesting questions to the table. Which models of internet-distributed television are succeeding in different countries, and why? What frameworks help us explain and talk about television in a period of such a variety of industrial practices?

This article has two aims. The first is to introduce and set a context for the current Media Industries special section, Global Internet Television. The second is to reflect on the current landscape of research around this topic and to identify key conceptual challenges facing media industry scholars. We do this via a series of seven "provocations," each of which addresses an area that has produced uncertainty in industrial, trade, and even scholarly 
understandings. These provocations are intended as gentle correctives to common misconceptions. We hope that these provocations may be of interest to researchers and students and that they may contribute to future theory-building.

\section{Disaggregating the Field}

A wide variety of terms are currently in use within industry and scholarly discourse to describe the online distribution of television content: internet television, internetdistributed television, online television, internet video, web TV, streaming, video on demand, Internet Protocol Television (IPTV), and so on. At times, the terms are used as synonyms, and at others to refer to a specific set of industry practices, although the boundaries around each term are highly porous. Our focus here is on the subset of services described by Amanda Lotz as "internet-distributed television"-that is, online portals distributing series produced in accord with professionalized, industrial practices of the television industry. ${ }^{4}$ Internetdistributed television is thus a subcategory of internet-distributed video, such that the broader category of video encompasses internet-distributed film (made according to the industrial logics of film industries) and the vast array of video produced outside these industry structures that the affordances of internet distribution now enable to circulate. All of this video is fascinating to study, but the essays collected here are primarily concerned with questions and issues related to industrial formations of internet-distributed video that intersect with, emerge from, or are identifiable as consistent with the logics of television.

The wide variation both within and beyond the category of internet-distributed television poses analytical challenges for media industry research. Clearly, there is no singular internetdistributed television "industry" distinct from established film and television industries. Many services offer the products of both television and film industries, whereas others blend user-generated video and television industry products. Nor can we easily designate a separate streaming industry comprising only internet-distributed services, as many established television players now utilize internet distribution as well as broadcast and cable/satellite. In other words, the field is composed of a series of complex, interlocking submarkets that integrate legacy and new players who provide different kinds of content to different audiences. Each submarket has its own idiosyncratic geography, regulatory conditions, and industrial practices. Consequently, when studying internet-distributed television services it is helpful to disaggregate services according to factors such as the following:

- Geography: Does the service operate quasi-globally (Netflix), or is it restricted to certain nations or regions (Blim, Hulu, Rakuten TV, iFlix)?

- Business model: Does it rely on a transactional payment (iTunes), advertising (Stream. cz), or subscription fee (Netflix)? Is it funded as public-service media through taxation or TV licenses (BBC iPlayer, NRK TV)? Does it combine free, transactional, and subscription models (YouTube)?

- Non/linearity: Is it a video on demand service, a linear stream, or both (Hulu)? Does it offer any time-sensitive content, such as sports and news (Hotstar)? 
- Ownership: Is it purely a video service? Is it part of a larger television service (Now TV)? Is it offered as added value to encourage another transaction (Amazon Prime Video) or technology purchase (Apple)?

- Library structure: Is it actively curated (Netflix)? Is it a catch-up service (BBC iPlayer) or does it offer a longer-duration library? Does it allow user uploads alongside professional content (YouTube, Youku)? Does it allow downloading of content?

These are just a few illustrative distinctions, but they may help to illuminate differences between, say, YouTube and Youku, or between Blim and BBC iPlayer. While internetdistributed television services are frequently conflated in industry discussions, the practices by which they operate are often fundamentally different, and these differences make sector-level claims and theorizing difficult. Beyond these characteristics of the services, internet-distributed television markets are also profoundly shaped by internet infrastructures that add differentiation to already significant variation in cultural expectations of television. Just as the content, industry organization, and experience of television have varied around the globe, the availability, norms, and practices of internet-distributed television are likewise diverse.

\section{Seven Provocations for Internet-Distributed Television Researchers}

It is still early days for internet-distributed television, and the players and practices are constantly changing. Some-even several-of the services considered here may be gone in five years, and those that remain may have made considerable adjustment in strategy, library, and functionality. Although internet-distributed television shares many features with its broadcast, cable, and satellite-distributed precursors, the affordances it enables also allow many adjustments in television so that the dominant players, industrial practices, viewer uses, and textual norms are difficult to predict and likely to remain as varied as the services and their value propositions. Any claims of internet-distributed video or television are thus inherently fleeting. Nonetheless, we find enough evidence to suggest some preliminary claims that we hope generate broader conversation and empirical investigation.

The Theoretical and Industrial Frameworks Developed for Past Forms of Television Require Reexamination

Distribution technologies are not determinant, but they enable and discourage varied industrial practices and user behaviors. As a result, internet-distributed television differs from the norms characteristic of broadcast, cable, and satellite distribution. The caution here is both not to discard everything learned from other distribution technologies and not to believe it all applies in the same way. For example, established theory leads to understandable concern about "cultural imperialism" in considering a service such as Netflix that is based in the United States and distributes a predominantly US catalog of programming. ${ }^{5}$ This concern is well placed, but scholars must also be open to investigating whether the affordances of internet distribution alter programming strategies and even provide commercial incentives 
for the provision of more diverse catalogs. Previous distribution technologies were limited by schedule scarcity; nonlinear, internet-distributed television does not have the capacity constraint of a schedule, although it remains limited by budgets for licensing/creating programming. In linear distribution, the scheduling of American content by non-US networks prevented the simultaneous availability of local content, but nonlinear libraries are not limited in this way. It remains to be seen what types of library strategies prove viable and whether they might encourage a broader range of options than was characteristic of scheduled, mostly ad-supported, television.

On that point, many internet-distributed services are subscriber rather than advertiser funded. This places greater imperative on including content of such interest that viewers will subscribe. Some evidence already exists that Netflix recognizes that it cannot gather a base of subscribers by serving up only US content or by creating "placeless" or delocalized stories and characters. Approaching our studies with an eye to both the limits and continued value of critical theories and understandings ensures openness to the greatest range of possibility. All the existing understandings will not map neatly onto internet-distributed television, nor will entirely new critical frameworks be required. The valuable insights emerge from identifying why particular changes or continuities occur.

Just as critical theories must be reevaluated in new contexts, so too must understandings of industrial strategies and behaviors be reassessed. So much of what is known of "television" is true of the historically most pervasive form of television-that distributed by broadcast technology and funded by advertisers. Internet-distributed television adjusts not only the cultural implications of television but also many of the practices, behaviors, and norms assumed in its scholarship. The paradigm of previous behavior functions as a lens we must not assume. Steady, even significant, change will continue and our claims require specificity. Few assertions can be made of "Netflix," but rather are claims of "early phase Netflix," "Netflix's strategy for large language markets," or "Netflix's approach to commissioning original children's series."

\section{Internet-Distributed Television Depends on Where You Are}

Graeme Turner and Jinna Tay famously observed that "the answer to the question 'What is television?' very much depends on where you are." television, a location-dependent term that evokes a wide variety of associations and histories. In much of the English-speaking world, the phenomenon is strongly associated, at this moment, with Netflix, but in other countries it is just as likely to refer to a telco's IPTV service, a smart-TV app, or an illegal streaming website or "TV box." Hence it is necessary to approach industry typologies, and histories, with some caution. ${ }^{7}$

Attending to the specificities of particular countries helps us to understand why internetdistributed television has followed distinct evolutionary paths and why media industry conversations may look quite different in different places. In the United States, services such as Netflix mostly complement the existing prevalence of multichannel service use, and internet-distributed channel bundles-virtual multichannel video programming distributors (vMVPDs)-have become a new competitor in offering multichannel service, but these 
phenomena do not directly map onto other countries' experiences. In Western Europe, the competitive conditions are different because of the longer tradition of public-service broadcasting and the active involvement of telcos and pay-TV providers in the development of internet-distributed services. This is also true in East Asia, especially Korea, with its highly developed streaming economy dominated by vertically integrated chaebols that have built internet-distributed services into their established internet and pay-TV offerings. ${ }^{8}$ Meanwhile, Chinese government policies fostering the growth of national tech companies and restricting foreign competition have led to the growth of "BAT" (Baidu/Alibaba/Tencent), which now comprehensively dominate online video markets. BAT have borrowed ideas from Silicon Valley (Youku's imitation of YouTube) while also creating their own innovative platforms that combine a range of video, e-commerce, and informational services in a way that has no direct equivalent in the United States or Europe. Our point here is that these diverse market and regulatory structures make it difficult to talk about internet-distributed television as a singular phenomenon.

\section{All Internet-Distributed Video Does Not Occupy the Same Competitive Field}

Too often, accounts of internet-distributed television presume services offering different value propositions are engaged in a winner-take-all battle. This is evident in the zero-sum logic in much industry and media commentary-for example, the assumption that Disney's creation of its own subscription video on demand (SVOD) service must entail a mortal threat to Netflix. The work in this issue suggests a different scenario. Internet-distributed television is a category that includes a wide range of services and overlapping competitive fields. The services certainly all compete for viewers' attention, but markets in this domain are multifaceted and evolving rapidly.

A more productive way to approach the issue of competition is to think about points of contact between services. Many services are complementary; some are competitive, and the competitive fields in which they operate are highly variable. Some internet video services are competing for advertising; some are targeting distinct niche markets through subscription or other models; some are generating their own intellectual property and licensing it to others, whereas others offer almost entirely licensed catalogs; some are components of larger screen industry enterprises; some are wholly or partly supported by government funding. Viewers' different pleasures and priorities-in concert with the capabilities of the distribution technology-enable a multifaceted field of internet-distributed video to coexist. Services might be viewed as complementary as a result of different underlying industrial strategies (ad-supported video on demand [AVOD] vs. SVOD) or based on the nature of the library (superstore breadth vs. niche depth).

In this environment, a few high-profile services certainly exercise increasing power in shaping markets and wielding influence. But there are many services that are not in direct competition and will not be readily substituted for others. Internet-distributed video services are creating dynamic new markets, and they are changing existing markets in unpredictable ways. Understanding these new competitive fields will be the departure point for effective public policy debate and intervention. 
We Should Not Presume Internet Distribution

Is on a Path to Replace Other Distribution Technologies

There is as much evidence of coexistence, evolution, and reconfiguration in the history of media distribution as replacement. Although disruption of print and recorded music industries by internet distribution has been severe, there are medium-specific reasons to speculate that the experience of video may differ. Rather than pittinglegacy and internet-distribution technologies against the other in either/or narratives, it is valuable to consider how the emergence of internet-distributed television might influence adaptation and adjustment of services using other distribution technologies. Internet-distributed television services expand television's ecosystem, and all existing models seem likely to persist in some capacity for the near term.

That said, although internet-distributed services may not replace broadcasting or cable/ satellite distribution, the competitive field for these distribution technologies has been forever changed. Internet-distributed services do not have to replace-or even become dominant-to make the norms of previous distributors unworkable. Advertising-based services may face the loss of available attention as viewers spend more time with subscriberfunded services, and other market dynamics between producers and distributors built on their control of the marketplace may founder as viewers have more choice in services and service providers. We will need ongoing investigation of the dialectic between legacy technologies' adaptations and the value propositions viewers find compelling, and the forces that emerge to obstruct the playing field.

Prior television industry scholarship provides insights into this dialectic between new and legacy technologies. Writing a decade ago about transnational satellite television services, Jean Chalaby emphasized that satellite television constituted "simply another layer added to the existing local, national and regional communications systems" rather than a wholesale disruption of existing television industries. ${ }^{9}$ In his book World Television, Joseph Straubhaar used a similar metaphor-"a multilayered world of television"-to describe the coexistence of distribution technologies. ${ }^{10}$ We argue that the advent of internet-distributed services should be seen in a similarly qualified way: as an additional layer on top of what already exists. These newer services exist alongside, and interact with, broadcast, satellite, cable, and free-to-air television. The affordance of nonlinear delivery is a notable characteristic of internet-distributed television that leads to its integration into, negotiation of, and distinction from preexisting industrial formations established for other distribution technologies. As such, the services do not displace or replace in any straightforward way, but add further complexity to existing environments.

\section{Internet-Distributed Television Can and Will Be Regulated}

New technologies and new digital services often emerge in a glowing halo of de facto regulatory immunity: There are many reasons for their burgeoning growth outside existing policy and legal frameworks, and many rationales ready for allowing them to remain there. Global industry realities diverge sharply from the old media policy concepts, which have long been mortgaged to linear broadcast models and nationally defined services. In many countries, the appearance of new on-demand services has had the effect of loosening the rules over 
television content. However, the transnational aspects of some internet-distributed television services, and their nonlinear features, do not exempt them from public and policy interests in audiovisual media or from the degree of private regulation in this space. Demands for cultural policy relating to locally produced content, children's content, and national services, and for market regulation where dominant players are emerging, have a long history and are unlikely to disappear (witness the Digital Single Market policies in Europe). In authoritarian and illiberal regimes, internet-distributed television is already controlled and closely monitored by governments, alongside social media. ${ }^{11}$ In liberal democracies, some services are already governed by policy in the sense that they benefit from public support, ${ }^{12}$ and there are many proposals for interventions in the production and distribution of content and at the level of market competition. There is no reason to imagine that internet-distributed services cannot be licensed and regulated if governments wish to do so-with the proviso of course that informal services will persist alongside regulated media.

The policy landscape of internet-distributed television is therefore unstable, with two main global fault lines. The first cuts across the screen industries. Television industry dynamics are stressed, with the weight of regulation concentrated on the legacy distribution systems. Consolidation of ownership is one response by legacy industries struggling to compete with those not subject to the same rules; another is to call for a redistribution of the regulatory burden to new distribution technologies (e.g., local content obligations for internet-distributed services) or for regulation of publicly funded services to be curtailed (as when legacy TV operators decry unfair "competition" from public-service broadcasters' digital operations). ${ }^{13}$ The second fault line is political. In advanced capitalist countries, the liberal consensus over the proper limits of media regulation is now under increasing pressure from a wave of reactive, populist, and illiberal leaders-many of whom are deeply critical of both old and new, and public and private, media operations. Both factors make the prospects for and timeline of internet-distributed television regulation uncertain.

\section{Content Is Not Necessarily the Primary Explanation of}

Viewer Adoption or Use of Internet-Distributed Television Services

Training in fields such as film and media studies biases us toward content and programming, but we are wise to blend this background with the emphases of information and technology studies that prioritize interface and experience. This, of course, is a line that must be tread carefully-we do not want to be technological determinists and overvalue functionality-but at this point, the conversation about internet-distributed television tends to overemphasize programming at the expense of how these services deliver a different viewing experience from linear norms. Factors of experience and convenience may be just as important as subtle program differences to understanding service adoption and use.

There is a larger challenge here for scholars working in this area. As yet, we lack an agreedupon vocabulary for describing the experiential dimensions of internet-distributed television. User practices of searching, browsing, scrolling, swiping, recommending, and favoriting require expansion of existing understandings of audience behaviors. Moreover, the use of "binging" to describe viewing consecutive episodes-whether two or ten-diminishes the utility of the term and such varied behaviors warrant precise understanding. Previous 
attempts to grapple with the embodied, experiential dimensions of television technologies provide important clues, as do emerging audience studies and reception theory. ${ }^{14}$ However, further empirical study of how viewers use and interact with these services is needed before we can theorize the experiential dimensions of internet-distributed television in ways that are conceptually robust.

For media industry research, it will be especially important to reconcile experience and convenience factors with political economy. Research must be attentive to the more subtle manifestations of these processes in everyday user experience-such as how the presence or absence of a Netflix button on a remote control or the opaque discoverability and promotion of content within portals, platforms, and multichannel video programming distributor (MVPD) interfaces unwittingly guide behavior-and also remain alert to macro-level issues such as control, ownership, and integration. These subtle structures of the user environment, which relate to political economy and experience, constitute an emerging frontier for media industry research on internet-distributed television.

We Should Not Presume Current Formations

Are Predictive of What Is Yet to Come

Examining internet-distributed television in 2018 requires considerable humility. Although internet-distributed television has become too profound to be ignored, everything about it remains preliminary and indefinite. It is necessary to begin building conceptual frameworks and advancing claims about industrial dynamics and cultural significance while also being mindful that such claims might ultimately only prove true of an "initial" version of internetdistributed television or the "marketplaces of internet-distributed television of 2018." Past communication and media innovation feature enough change to inspire reasonable caution to claims of replacement or continued linear change. Thus, we must identify, understand, and monitor emerging industrial and audience practices, but also do so with the knowledge that we may be only witnessing preliminary formations. It is certainly the case that the companies we study are as uncertain about the opportunities and possibilities of this distribution technology as we are, and that their preliminary practices and strategies are every bit as speculative as our initial conceptualizations.

Answers to many important questions remain elusive: Can a marketplace of mainstream, multidimensional providers such as Netflix and iQiyi as well as niche providers coexist? What kinds of internet-distributed television will emerge to cater to the needs of low-income countries and other underserved markets? How will original production practices evolve within these companies, and what future interactions with established players might occur? How will these internet-distributed television services be regulated and with what effect? The collection of articles here begins to answer these questions, providing rich insight into an especially volatile area of the media industries.

\section{Introducing the Special Section}

The six articles published in this special section of Media Industries engage the questions above through detailed case studies of internet-distributed television services (and one 
infrastructure provider) in Central and Eastern Europe, Africa, the Asia-Pacific, and North America. The services studied here range from large, multinational services that are also multilocal/multiregional (Netflix, HBO), through to smaller operators catering to national and regional audiences. While not constituting a global survey-surely an impossible taskthe articles together provide a richly detailed, multisited perspective on how internetdistributed television is evolving to suit very different markets and audiences.

Aniko Imre's article "HBO's e-EUtopia" revisits the history of HBO's European operations in the context of current debates about the European Digital Single Market. Establishing an early foothold in Hungary after the fall of the Berlin Wall, HBO reversed the typical trajectory of US-based television channels expanding into Europe by investing first in the former Soviet states, rather than in the more affluent Western and Northern European markets. Imre explores the surprising synergy between EU media policies and HBO's commercial strategy in Europe (which mixes internet-distributed and linear television models). Arguing that HBO has "given a viable representational form to a pan-European identity promoted by the European Union," Imre offers a thought-provoking analysis of how recent HBO format adaptations embody and extend this vision of Europe.

In "Web TV as public service," Dorota Vašíčková and Petr Szczepanik explore the evolution of the Czech service Stream.cz and its success developing original, short-form series. Where public-service broadcasters have struggled with a strategy for internet-distributed video service in Eastern Europe, Stream.cz provides a rich case of the opportunities available for a commercial short-form service to complement linear public-service efforts. Explored through the case of Stream.cz's five-season, short-form, original series The Blaník Bureau, Vašíčková and Szczepanik illustrate Stream.cz's continuous evolution and uncertain future.

Lindiwe Dovey's article "Entertaining Africans: Creative innovation in the (internet) television space" provides a wide-ranging account of how internet-distributed television is evolving in Africa. Drawing on interviews with streaming start-ups and established pay-TV operators, Dovey explores the infrastructural challenges of providing internet-distributed television in Africa. She also identifies some of the strategies employed by operators in response to these challenges, such as apps and short-form content designed for mobile-only (or "supersmall screen") users, transnational partnerships between African television providers, and new combinations of linear and nonlinear services. Challenging the colonial vision of Africa as a space of technological underdevelopment, Dovey's article paints a vivid picture of media industry innovation and experimentation.

In "Creating children's television for SVODs," Anna Potter offers an illuminating study of Netflix's "Original" commission for children, the Australian animated series Bottersnikes and Gumbles (2016). Children's television has long been a focus of national screen and cultural policy; the Bottersnikes example enables Potter to ask important questions about the future place of this much-debated form beyond the regulated linear environment of broadcasting. The result is a valuable contribution to our understanding of internet-distributed television, at three levels. First, in terms of policy and political economy, the article explores the interactions between the global industry logics of the Netflix service and the nationally bounded policy structures of children's television. It then considers a critical question: Is there anything distinctive about this production, given Netflix's role in funding and distribution? 
Finally, the article draws out the complex relations between Netflix and its public-service broadcasting partners in the United Kingdom and Australia.

What happens when a global service such as Netflix enters a highly regulated national television market? Graeme Turner's article, "Netflix and the reconfiguration of the Australian television market," draws out the significance of this change: a radical, multisided restructuring, with implications that are not yet clear. Netflix, he argues, has upended long-standing policy settings and settlements; it has transformed the economics of the industry, for both pay and free-to-view broadcasters, and, perhaps of most significance, it has changed what Australians think television is. What was once a managed, highly structured, national system is now decisively transnational-a shift underlined by both the purchase of the Ten broadcasting network by the US CBS network and the public reaction to that acquisition.

Steven Secular's article "Games without frontiers: Streaming sports and the evolution of digital intermediaries" examines an industry sector crucial to enabling internet-distributed television, but one largely obscured from audiences who use these services. He explores the history and role of "streaming intermediaries" such as NeuLion and BAMTech that are responsible for providing the infrastructures that enable video content to be distributed over the internet. Secular focuses particularly on intermediaries that have developed to distribute sports programming and explores how these streaming intermediaries repackage US sports for a global audience. His article provides a rare insight into the back-end infrastructure services that make internet-distributed television possible.

These six articles collectively deepen and extend disciplinary knowledge of internetdistributed television, inviting us to see the phenomenon in transnational perspective. We thank the authors for their valuable contributions, which represent an important step in what we hope is a much longer conversation.

\section{Acknowledgments}

The idea for this special issue arose from the Global Internet TV Consortium, a research network co-founded by Amanda Lotz and Ramon Lobato in 2016 to study the international Netflix rollout and which now features twenty-one scholars from around the world. Discussions among the Consortium provided the initial basis for the idea of this special issue, and an open call for papers was subsequently issued. We extend thanks to all members of the Consortium for sharing their expertise and ideas on this topic.

${ }^{1}$ Amanda D. Lotz is a Professor of Media Studies at the University of Michigan and a Fellow at the Peabody Media Center. She is the author, coauthor, or editor of eight books that explore television and media industries, including We Now Disrupt This Broadcast: How Cable Transformed Television and the Internet Revolutionized It All, The Television Will Be Revolutionized and Portals: A Treatise on InternetDistributed Television. Ramon Lobato is Senior Research Fellow in the School of Media and Communication at RMIT University, Melbourne. His books include Shadow Economies of Cinema (2012), The Informal Media Economy (2015 with Julian 
Thomas), and Geoblocking and Global Video Culture (2016 with James Meese). His latest monograph, Netflix Nations: The Geography of Digital Distribution, will be published this year by NYU Press. He is a member of the Media Industries editorial collective. Julian Thomas is Director of the Social Change research platform and Professor of Media and Communications at RMIT in Melbourne. His recent publications include Internet on the Outstation: The Digital Divide and Remote Aboriginal Communities (with Ellie Rennie and others, INC, 2016), Measuring the Digital Divide: The Australian Digital Inclusion Index (2016), The Informal Media Economy (with Ramon Lobato, Polity, 2015), and Fashioning Intellectual Property (with Megan Richardson, Cambridge University Press, 2012).

2 This research is supported by the Australian Research Council Discovery Early Career Scheme (project number DE150100288).

${ }^{3}$ See, among others, José M. Alvarez-Monzoncillo, Watching the Internet: The Future of TV? (Lisbon: Formalpress, 2011); Jennifer Holt and Kevin Sanson, Connected Viewing: Selling, Streaming, \& Sharing Media in the Digital Age (London: Routledge, 2013); Amanda D, Lotz, Portals: A Treatise on Internet-Distributed Video (Ann Arbor: Maize Books, 2017); Catherine Johnson, "Defining Television in an Online Video Ecosystem" (conference paper presented at the Trans TV Conference, University of Westminster, London, September 13-15, 2017), https://nottingham.academia. edu/CatherineJohnson; Catherine Johnson, "Beyond Catch-Up: VOD Interfaces, ITV Hub and the Repositioning of Television Online," Critical Studies in Television 12 (2, 2017): 121-38; Tom Evens and Karen Donders, Platform Power and Policy in Transforming Television Markets (Basingstoke: Palgrave Macmillan, 2018).

${ }^{4}$ Lotz, Portals.

${ }^{5}$ A number of scholars have analyzed the impact of Netflix on global markets and associated claims of US media domination. See: Ira Wagman, "Talking to Netflix with a Canadian Accent: On Digital Platforms and National Media Policies," in Reconceptualising Film Policies, ed. Nolwenn Mingant and Cecilia Tirtaine (London: Routledge, 2017), 209-21; Ramon Lobato, Netflix Nations: The Geography of Digital Distribution (NY: New York University Press, 2018); Emilia Zboralska and Charles H. Davis, "Transnational Over-the-Top Video Distribution as a Business and Policy Disruptor: The Case of Netflix in Canada," The Journal of Media Innovations 4 (1, 2017): 4-25; and articles by Graeme Turner and Anna Potter in this issue of Media Industries.

${ }^{6}$ Graeme Turner and Jinna Tay, Television Studies After TV: Understanding Television in the Post-Broadcast Era (London: Routledge, 2009), 8.

${ }^{7}$ While Silicon Valley companies loom large in English-language media histories, we should not forget the role of other companies, especially in East Asia, that were integral to the development of mobile, over-the-top (OTT), and Internet Protocol Television (IPTV) platforms, formats, and payment systems. Marc Steinberg (2017), for example, stresses the importance of the Japanese mobile platform iMode as a key precursor of today's internet-distributed television platforms, gesturing toward a different, transnational historiography of media industry transformation.

${ }^{8}$ Eun-A Park, "Why the Networks Can't Beat Netflix: Speculations on the US OTT Services Market," Digital Policy, Regulation and Governance 19 (1, 2017): 21-39. 
${ }^{9}$ Jean Chalaby, Transnational Television in Europe: Reconfiguring Global Communications Networks (London: I.B. Tauris, 2009), 232.

${ }^{10}$ Joseph Straubhaar, World Television: From Global to Local (London: SAGE, 2007), 1.

${ }^{11}$ Elaine Zhao, "The Bumpy Road towards Network Convergence in China: The Case of Over-the-Top Streaming Services," Global Media and China 2 (1, 2017): 28-42.

${ }^{12}$ Stuart Cunningham and David Craig, Social Media Entertainment: The New Intersection of Hollywood and Silicon Valley (NY: New York University Press, 2019).

${ }^{13}$ For historical context on these claims, see Karen Donders, "Fighting a (Lost) Battle? An Analysis of 20 Years of Private Television Complaints against the Public Funding of Public Service Broadcasting," in Private Television in Western Europe: Content, Markets, Policies, ed. Karen Donders, Caroline Pauwels, and Jan Loisen (Basingstoke: Palgrave, 2013), 214-28.

${ }^{14}$ See, for example, Mareike Jenner, "Is this TVIV? On Netflix, Arrested Development and Binge-Watching," New Media E Society 18 (2, 2014): 257-73; Rhiannon Bury, Television 2.0: Viewer and Fan Engagement with Digital TV (NY: Peter Lang, 2017); and Deborah Castro, "B-WATCH: An Interdisciplinary Approach toward Analyzing Binge Watching" (paper presented at Trans TV Conference, University of Westminster, London, September 14, 2017). For the longer tradition of work on television, experience, and domesticity, see: Lynn Spigel, Make Room for TV: Television and the Family Ideal in Postwar America (Chicago: University of Chicago Press, 1992); Shaun Moores, Interpreting Audiences: The Ethnography of Media Consumption (London: SAGE, 1993); and Roger Silverstone, Television and Everyday Life (London: Routledge, 1994).

\section{Bibliography}

Alvarez-Monzoncillo, José M. Watching the Internet: The Future of TV? Lisbon: Formalpress, 2011.

Bury, Rhiannon. Television 2.0: Viewer and Fan Engagement with Digital TV. New York: Peter Lang, 2017.

Chalaby, Jean. Transnational Television in Europe: Reconfiguring Global Communications Networks. London: I.B. Tauris, 2009.

Cunningham, Stuart and David Craig. Social Media Entertainment: The New Intersection of Hollywood and Silicon Valley. New York: New York University Press, 2019.

Donders, Karen. "Fighting a (Lost) Battle? An Analysis of 20 Years of Private Television Complaints against the Public Funding of Public Service Broadcasting." In Private Television in Western Europe: Content, Markets, Policies, edited by Karen Donders, Caroline Pauwels and Jan Loisen, 214-28. Basingstoke: Palgrave, 2013.

Evens, Tom and Karen Donders. Platform Power and Policy in Transforming Television Markets. Basingstoke: Palgrave Macmillan, 2018.

Holt, Jennifer and Kevin Sanson. Connected Viewing: Selling, Streaming, E Sharing Media in the Digital Age. London: Routledge, 2013. 
Johnson, Catherine. "Beyond Catch-Up: VOD Interfaces, ITV Hub and the Repositioning of Television Online." Critical Studies in Television 12, no. 2 (2017): 121-38.

Johnson, Catherine. "Defining Television in an Online Video Ecosystem." Conference paper presented at the Trans TV Conference, University of Westminster, London, September 15, 2017. https://nottingham.academia.edu/CatherineJohnson.

Lobato, Ramon. Netflix Nations: The Geography of Digital Distribution. New York: New York University Press, 2018.

Lotz, Amanda D. Portals: A Treatise on Internet-Distributed Video. Ann Arbor: Maize Books, 2017.

Moores, Shaun. Interpreting Audiences: The Ethnography of Media Consumption. London: SAGE, 1993.

Park, Eun-A. "Why the Networks Can't Beat Netflix: Speculations on the US OTT Services Market." Digital Policy, Regulation and Governance 19, no. 1 (2017): 21-39.

Silverstone, Roger. Television and Everyday Life. London: Routledge, 1994.

Spigel, Lynn. Make Room for TV: Television and the Family Ideal in Postwar America. Chicago: University of Chicago Press, 1992.

Steinberg, Marc. "A Genesis of the Platform Concept: i-mode and Platform Theory in Japan." Asiascape: Digital Asia 4, no. 3 (2017): 184-208.

Straubhaar, Joseph. World Television: From Global to Local. London: SAGE, 2007.

Turner, Graeme and Jinna Tay. Television Studies After TV: Understanding Television in the Post-Broadcast Era. London: Routledge, 2009.

Wagman, Ira. "Talking to Netflix with a Canadian Accent: On Digital Platforms and National Media Policies." In Reconceptualising Film Policies, eds. Nolwenn Mingant and Cecilia Tirtaine, 209-21. London: Routledge, 2017.

Zboralska, Emilia and Charles H. Davis. "Transnational Over-the-Top Video Distribution as a Business and Policy Disruptor: The Case of Netflix in Canada." The Journal of Media Innovations 4, no. 1 (2017): 4-25.

Zhao, Elaine. "The Bumpy Road towards Network Convergence in China: The Case of Overthe-Top Streaming Services." Global Media and China 2, no. 1 (2017): 28-42. 